\title{
The ligational behavior of a phenolic quinolyl hydrazone towards copper(II)- ions
}

\author{
Hussein S Seleem*, Gaber A El-Inany, Bashir A El-Shetary, Marwa A Mousa
}

\begin{abstract}
Background: The heterocyclic hydrazones constitute an important class of biologically active drug molecules. The hydrazones have also been used as herbicides, insecticides, nematocides, redenticides, and plant growth regulators as well as plasticizers and stabilizers for polymers. The importance of the phenolic quinolyl hydrazones arises from incorporating the quinoline ring with the phenolic compound; 2,4-dihydroxy benzaldehyde. Quinoline ring has therapeutic and biological activities whereas, phenols have antiseptic and disinfectants activities and are used in the preparation of dyes, bakelite and drugs. The present study is planned to check the effect of the counter anions on the type and geometry of the isolated copper(II)- complexes as well as the ligational behavior of the phenolic hydrazone; 4-[(2-(4,8-dimethylquinolin-2-yl)hydrazono)methyl] benzene-1,3-diol; $\left(\mathrm{H}_{2} \mathrm{~L}\right)$.

Results: A phenolic quinolyl hydrazone $\left(\mathrm{H}_{2} \mathrm{~L}\right)$ was allowed to react with various copper(II)- salts $\left(\mathrm{Cl}^{-}, \mathrm{Br}^{-}, \mathrm{NO}_{3}{ }^{-}\right.$, $\left.\mathrm{ClO}_{4}{ }^{-}, \mathrm{AcO}^{-}, \mathrm{SO}_{4}{ }^{2-}\right)$. The reactions afforded dimeric complexes $\left(\mathrm{ClO}_{4}{ }^{-}, \mathrm{AcO}^{-}\right)$, a binuclear complex $\left(\mathrm{NO}_{3}{ }^{-}\right)$and mononuclear complexes (the others; $\mathrm{Cl}^{-}, \mathrm{Br}^{-}, \mathrm{SO}_{4}{ }^{2-}$ ). The isolated copper(II)- complexes have octahedral, square pyramid and square planar geometries. Also, they reflect the strong coordinating ability of $\mathrm{NO}_{3}{ }^{-}, \mathrm{Cl}^{-}, \mathrm{Br}^{-}, \mathrm{AcO}^{-}$ and $\mathrm{SO}_{4}{ }^{2-}$ anions. Depending on the type of the anion, the ligand showed three different modes of bonding viz. $(\mathrm{NN})^{0}$ for the mononuclear complexes $(\mathbf{3}, \mathbf{4}, \mathbf{6})$, (NO)- with $\mathrm{O}^{-}$bridging for the dimeric complexes $(\mathbf{1}, \mathbf{5})$ and a mixed mode $\left[(\mathrm{NN})^{0}+(\mathrm{NO})^{-}\right.$with $\mathrm{O}$ - bridging] for the binuclear nitrato- complex (2).

Conclusion: The ligational behavior of the phenolic hydrazone $\left(\mathrm{H}_{2} \mathrm{~L}\right)$ is highly affected by the type of the anion. The isolated copper(II)- complexes reflect the strong coordinating power of the $\mathrm{SO}_{4}{ }^{2-}, \mathrm{AcO}^{-}, \mathrm{Br}^{-}, \mathrm{Cl}^{-}$and $\mathrm{NO}_{3}{ }^{-}$ anions. Also, they reflect the structural diversity (octahedral, square pyramid and square planar) depending on the type of the counter anion.
\end{abstract}

\section{Background}

The heterocyclic hydrazones constitute an important class of biologically active drug molecules which have attracted attention of medicinal chemists due to their wide ranging pharmacological properties including iron scavenging and antitubercular activities [1-6]. The hydrazones have also been used as herbicides, insecticides, nematocides, redenticides, and plant growth regulators [5] as well as plasticizers and stabilizers for polymers $[7,8]$. Furthermore, some hydrazones are used as quantitative analytical reagents, especially in colorimetric and fluorimetric determination of metal ions [4-6]. The importance of the phenolic quinolyl hydrazones arises from incorporating the quinoline ring with the phenolic compound; 2,4-dihydroxybenzaldehyde. Quinoline ring has therapeutic and biological activities whereas, phenols have antiseptic and disinfectants activities and are used in the preparation of dyes, bakelite and drugs. The metal complexes of hydrazones have potential applications as catalysts [9], luminescent probes [10] and molecular sensors [11]. The present study is planned to check the effect of the counter anions on the type and geometry of the isolated copper (II)- complexes as well as the ligational behavior of the phenolic hydrazone; 4-[(2-(4,8-dimethylquinolin-2-yl) hydra-zono)methyl]benzene-1,3-diol; $\left(\mathrm{H}_{2} \mathrm{~L}\right)$. This work is an extension to our previous studies on the chelating ability of quinolyl hydrazones [12-14].

\footnotetext{
* Correspondence: hsseleem@yahoo.com

Department of Chemistry, Faculty of Education, Ain Shams University, Roxy, Cairo, Egypt
} 


\section{Results and discussion}

\section{Characterization of the hydrazone}

The investigated hydrazone; 4-[(2-(4,8-dimethylquinolin2-yl)hydrazono)methyl] benzene-1,3-diol; $\left(\mathrm{H}_{2} \mathrm{~L}\right)$ was prepared by a condensation reaction of 2-hydrazinyl-4,8dimethylquinoline with 2,4-dihydroxybenzaldehyde. The results of elemental analysis (Table 1) are in good harmony with the proposed formula. The IR spectrum (Table 2) showed bands at 3426, 3159 and $1603 \mathrm{~cm}^{-1}$ assignable to $v(\mathrm{OH}), v(\mathrm{NH})$ and $v(\mathrm{C}=\mathrm{N})$; respectively [15]. On the other hand, the electronic absorption spectra of the hydrazone in DMF exhibit two intense bands at 266 and $320 \mathrm{~nm}$ characteristic for $\pi-\pi *$ transitions of the aromatic and $\mathrm{C}=\mathrm{N}$ group, respectively. In addition, the band at $371 \mathrm{~nm}$ referred to a charge transfer (CT) transition [12]. The mass spectrum of the ligand showed the molecular ion and the base peaks at $m / z=307$ and 172 confirming its formula weight $(\mathrm{FW}=307.35)$. The mass fragmentation pattern (Scheme 1) supported the suggested structure of the ligand. Also, the ${ }^{1} \mathrm{H}$ NMR spectral data of the ligand in $\mathrm{d}_{6}$-DMSO relative to TMS (Figure 1) lend a further support of its structure. The signals due to $\mathrm{OH}$ and $\mathrm{NH}$ protons are disappeared upon deuteration.

\section{Characterization of the complexes}

The interaction of the phenolic hydrazone $\left(\mathrm{H}_{2} \mathrm{~L}\right)$ with several copper(II)- salts afforded mono- and binuclear as well as dimeric complexes depending on the type of the anion; Scheme 2. The dimeric (1 \&5) and the binuclear (2) complexes are formed via phenoxy bridging. In general, the isolated complexes reflect the strong coordinating power of the $\mathrm{SO}_{4}{ }^{2-}, \mathrm{AcO}^{-}, \mathrm{Br}^{-}, \mathrm{Cl}^{-}$and $\mathrm{NO}_{3}{ }^{-}$ anions relative to the non coordinating $\mathrm{ClO}_{4}{ }^{-}$anion [16]. Also, they reflect a variety of modes of bonding as well as various geometries (octahedral, square pyramid and square planar) depending on the type of the counter anion (Scheme 2). In addition, complexes (2-4 \&6) reveal the highest affinity of copper(II)-ions for $\mathrm{N}$-donors. For square pyramidal complexes $(\mathbf{1 , 2} \& 4)$, the apical position is occupied by $\mathrm{H}_{2} \mathrm{O}, \mathrm{NO}_{3}{ }^{-}$and $\mathrm{Br}^{-}$, respectively. Structural elucidation of the isolated complexes was achieved via elemental and thermal analyses, magnetic susceptibility and conductivity measurements as well as spectral studies viz. electronic, vibration, mass and ESR spectra.

\section{IR spectra of the complexes}

Comparison of the IR bands of the free phenolic hydrazone $\left(\mathrm{H}_{2} \mathrm{~L}\right)$ and its complexes revealed the following: (i) All complexes showed broad bands in the region 3423$3385 \mathrm{~cm}^{-1}$ due to $\mathrm{OH}$ stretches of either the phenolic or the associated water/methanol molecules. (ii) The strong band at $1603 \mathrm{~cm}^{-1}$ assignable to $v(C=N)$ stretch in the free ligand undergoes a shift to higher wave numbers (1641-1612 $\mathrm{cm}^{-1}$ ) upon complexation, supporting the coordination of the hydrazone linkage to all metal ions. This can be explained on the basis of the diminished repulsion between the lone pairs of electrons of the two adjacent $\mathrm{N}$ atoms upon complexation and hence, $\pi$ - electron delocalization [17]. (iii) The perchlorato and sulfato complexes $(\mathbf{1} \& \mathbf{6})$ showed the $v(\mathrm{~S}-\mathrm{O})$ or $v(\mathrm{Cl}-\mathrm{O})$ stretches around $1100 \mathrm{~cm}^{-1}$ [18]. Also, the nitrato complex (2) showed the $v(\mathrm{~N}-\mathrm{O})$ stretch at $1394 \mathrm{~cm}^{-1}$. (iv) In the acetato complex (5), the new band at $1635 \mathrm{~cm}^{-1} ; \mathrm{v}(\mathrm{C}=\mathrm{O})$, confirm the monodentate nature of the acetate ion.

\section{Conductivity and magnetic properties}

The molar conductance values (Table 2) of the current chelates in DMF $(1.0 \mathrm{mmol} / \mathrm{L})$ revealed a non- electrolytic

Table 1 Analytical and physical data of the copper(II)- phenolic complexes

\begin{tabular}{|c|c|c|c|c|c|c|c|c|}
\hline \multirow[t]{2}{*}{ No. } & \multirow{2}{*}{$\begin{array}{l}\text { Complex } \\
\text { F.W. }\end{array}$} & \multirow[t]{2}{*}{ Color } & \multirow{2}{*}{$\begin{array}{l}\% \\
\text { yield }\end{array}$} & \multirow{2}{*}{$\begin{array}{l}\text { m.p. } \\
\left({ }^{\circ} \mathrm{C}\right)\end{array}$} & \multicolumn{4}{|c|}{ Elemental analysis; \% Found/(Calcd.) } \\
\hline & & & & & $C$ & $\mathrm{H}$ & $\mathbf{N}$ & $\mathbf{M}$ \\
\hline & $\begin{array}{c}\left(\mathrm{H}_{2} \mathrm{~L}\right) ; \mathrm{C}_{18} \mathrm{H}_{17} \mathrm{~N}_{3} \mathrm{O}_{2} \\
(307.35)\end{array}$ & Yellow & 64 & 260 & $\begin{array}{c}70.50 \\
(70.28)\end{array}$ & $\begin{array}{c}5.68 \\
(5.53)\end{array}$ & $\begin{array}{c}13.66 \\
(13.67)\end{array}$ & - \\
\hline 1 & $\begin{array}{c}{\left[\mathrm{Cu}(\mathrm{HL})\left(\mathrm{H}_{2} \mathrm{O}\right)_{2}\right]_{2}\left(\mathrm{ClO}_{4}\right)_{2} \cdot 1 / 2 \mathrm{H}_{2} \mathrm{O} .1 / 4 \mathrm{MeOH}} \\
(1027.76)\end{array}$ & $\begin{array}{c}\text { Dark } \\
\text { violet }\end{array}$ & 49 & 145 & $\begin{array}{c}42.29 \\
(42.36)\end{array}$ & $\begin{array}{c}4.26 \\
(4.12)\end{array}$ & $\begin{array}{l}8.13 \\
(8.18)\end{array}$ & $\begin{array}{r}12.35 \\
(12.37)\end{array}$ \\
\hline 2 & $\begin{array}{c}{\left[\mathrm{Cu}_{2}(\mathrm{HL})_{2}\left(\mathrm{H}_{2} \mathrm{~L}\right)\left(\mathrm{NO}_{3}\right)_{2}\right] \cdot 1 \frac{1}{1} / 4 \mathrm{H}_{2} \mathrm{O} \cdot 23 / 4 \mathrm{MeOH}} \\
(1281.78)\end{array}$ & $\begin{array}{l}\text { Greenish } \\
\text { brown }\end{array}$ & 24 & $>300$ & $\begin{array}{c}53.12 \\
(53.17)\end{array}$ & $\begin{array}{c}5.02 \\
(4.92)\end{array}$ & $\begin{array}{c}12.02 \\
(12.02)\end{array}$ & $\begin{array}{c}9.95 \\
(9.92)\end{array}$ \\
\hline 3 & $\begin{array}{c}{\left[\mathrm{Cu}\left(\mathrm{H}_{2} \mathrm{~L}\right)\left(\mathrm{H}_{2} \mathrm{O}\right)_{2} \mathrm{Cl}_{2}\right] .11 / 8 \mathrm{H}_{2} \mathrm{O}} \\
(498.1)\end{array}$ & $\begin{array}{c}\text { Dark } \\
\text { brown }\end{array}$ & 30 & $>300$ & $\begin{array}{c}43.44 \\
(43.40)\end{array}$ & $\begin{array}{c}4.73 \\
(4.71)\end{array}$ & $\begin{array}{l}8.48 \\
(8.44)\end{array}$ & $\begin{array}{r}12.75 \\
(12.76)\end{array}$ \\
\hline 4 & $\begin{array}{c}{\left[\mathrm{Cu}\left(\mathrm{H}_{2} \mathrm{~L}\right)\left(\mathrm{H}_{2} \mathrm{O}\right) \mathrm{Br}_{2}\right] \cdot 1 / 2 \mathrm{H}_{2} \mathrm{O}} \\
(557.72)\end{array}$ & $\begin{array}{l}\text { Chocolate } \\
\text { brown }\end{array}$ & 34 & 247 & $\begin{array}{l}38.73 \\
(38.76)\end{array}$ & $\begin{array}{l}3.68 \\
(3.61)\end{array}$ & $\begin{array}{l}7.76 \\
(7.54)\end{array}$ & $\begin{array}{r}11.36 \\
(11.39)\end{array}$ \\
\hline 5 & $\begin{array}{c}{[\mathrm{Cu}(\mathrm{HL})(\mathrm{OAc})]_{2} \cdot \mathrm{MeOH}} \\
(889.91)\end{array}$ & $\begin{array}{l}\text { Greenish } \\
\text { brown }\end{array}$ & 53 & $>300$ & $\begin{array}{c}55.26 \\
(55.33)\end{array}$ & $\begin{array}{c}4.77 \\
(4.76)\end{array}$ & $\begin{array}{c}9.51 \\
(9.45)\end{array}$ & $\begin{array}{r}14.30 \\
(14.28)\end{array}$ \\
\hline 6 & $\begin{array}{c}{\left[\mathrm{Cu}\left(\mathrm{H}_{2} \mathrm{~L}\right)\left(\mathrm{H}_{2} \mathrm{O}\right)_{2} \mathrm{SO}_{4}\right] \cdot 2 \frac{1}{4} \mathrm{H}_{2} \mathrm{O}} \\
(543.52)\end{array}$ & $\begin{array}{l}\text { Dark } \\
\text { green }\end{array}$ & 14 & $>300$ & $\begin{array}{c}39.85 \\
(39.77)\end{array}$ & $\begin{array}{c}4.76 \\
(4.73)\end{array}$ & $\begin{array}{l}7.85 \\
(7.73)\end{array}$ & $\begin{array}{c}11.71 \\
(11.69)\end{array}$ \\
\hline
\end{tabular}




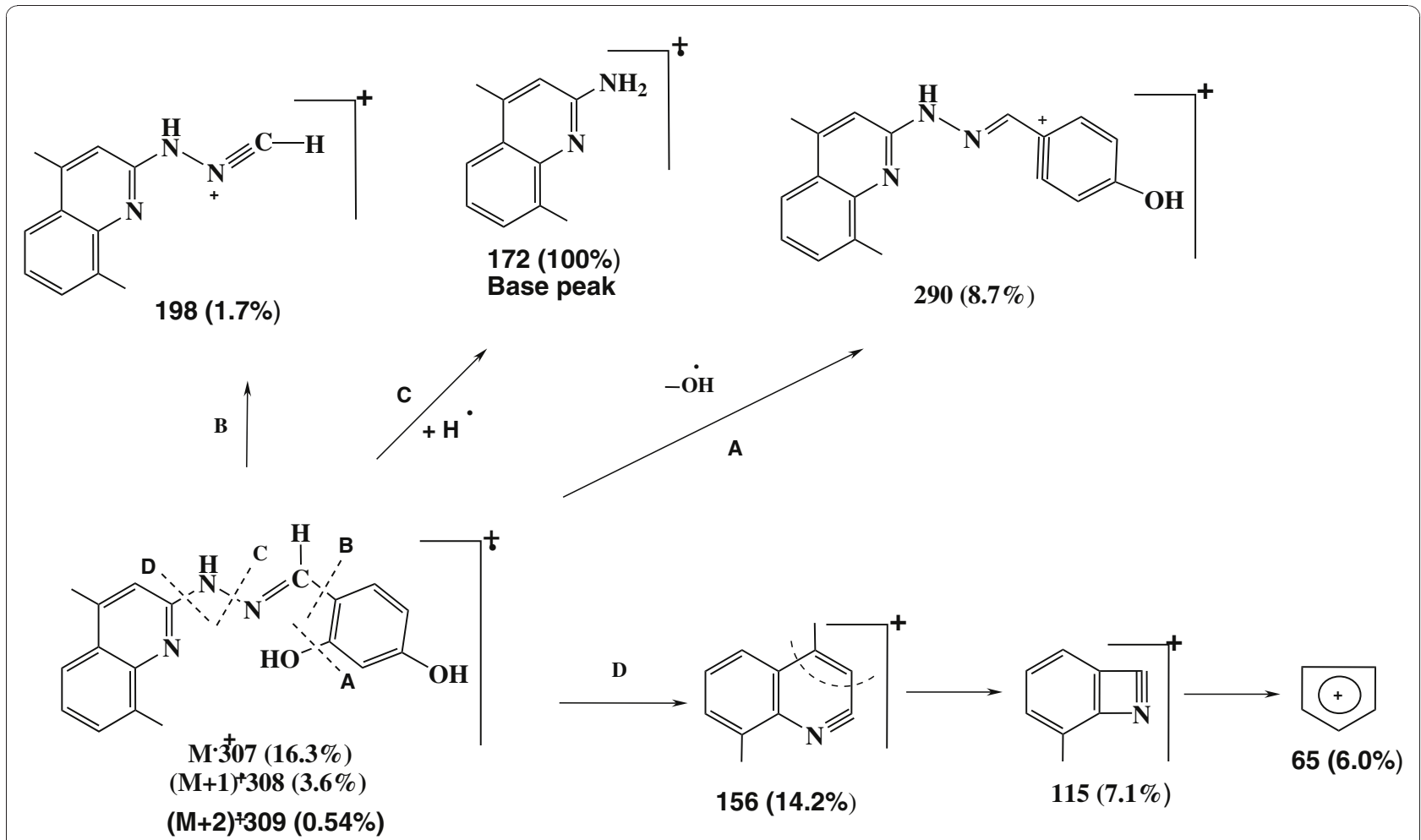

Scheme 1 Mass fragmentation pattern of the $\mathrm{H}_{2} \mathrm{~L}$ ligand.

nature of all complexes except the perchlorato- complex (1) which showed molar conductance of 175 and $\mathrm{Ohm}^{-1}$ $\mathrm{cm}^{2} \mathrm{~mol}^{-1}$ suggesting its 1:2 electrolytic nature. The complex (1) has $3 \mathrm{~mol}$ ions/mol $(+2,-1)$, one of which is bipositive. In case of complexes $\mathbf{2 - 4}$, the relatively high values of the molar conductance may be due to their partial dissociation in DMF solutions. However, they did not reach the previously reported values for 1:1 electrolytes in DMF solutions $\left(\sim 70-110 \mathrm{Ohm}^{-1} \mathrm{~cm}^{2} \mathrm{~mol}^{-1}\right)$ [19]. On the other hand, the copper(II)- complexes (1-6); $\mathrm{d}^{9}$-system exhibit $\mu_{\text {eff }}$ values in the range 1.33-2.01 B.M. (Table 2) indicating the presence of one unpaired electron. The subnormal $\mu_{\text {eff }}$ values for complexes $(\mathbf{1}, 2$ \& 5$)$ indicate $\mathrm{M}^{\mathrm{II}}-$ $\mathrm{M}^{\mathrm{II}}$ interactions in the solid state supporting either dimeric or binuclear nature of the complexes.

\section{Electronic, ESR and mass spectra}

Solution electronic spectra of all phenolic complexes in DMF (Figure $2 \&$ Table 2) are more or less similar and show a series of bands within the range 269-352 nm due to different intra- ligand transitions. Besides, the phenoxide to metal charge transfer band (LMCT transition) appears in the range $371-381 \mathrm{~nm}$. In addition, the copper (II)- complexes (1-6) display relatively less intense bands at $436-488 \mathrm{~nm}$ that arise from different $\mathrm{d}$ - $\mathrm{d}$ transitions of copper (II) [20]. The position and intensity of $d-d$ bands suggest a distorted square planar, square pyramid or $\mathrm{O}_{h}$ environment around copper (II)- ion. To obtain further information about the stereochemistry as well as the magnetic properties of the complexes, the ESR spectrum of complex 3 was recorded at room temperature (Figure 3). The shape and the feature of the obtained spectrum are consistent with the $\mathrm{O}_{\mathrm{h}}$ geometry around the metal ion. The ESR spectrum of $\left[\mathrm{Cu}\left(\mathrm{H}_{2} \mathrm{~L}\right)\left(\mathrm{H}_{2} \mathrm{O}\right)_{2} \mathrm{Cl}_{2}\right]$. $1 \frac{1}{8} \mathrm{H}_{2} \mathrm{O}(3)$ showed a broad symmetrical band centered on $\mathrm{g}_{\text {iso }}=2.155$ without resolved hyperfine structure. In particular, the absence of copper(II) hyperfine coupling is common in the solid state. Also, the absence of the forbidden magnetic dipolar transition at half field ( $c a .1600$ Gauss; $\mathrm{g}=4.0$ ) excluded the $\mathrm{Cu}-\mathrm{Cu}$ interaction and confirmed the mononuclearity of the complex [21]. The mass spectrum of complex $\mathbf{3}$, showed the molecular ion and the base peaks at m/e 495 and 45 confirming its formula weight $(\mathrm{FW}=498.1)$.

\section{Thermal properties}

The TGA data (Table 3) of the complexes showed good agreement with the results of elemental analysis. Inspection of the data revealed the following remarks: (i) Elimination of the solvated methanol/hydrated water molecules occurs in a separate step or overlapped with the removal of the coordinated ones. This stage is accompanied by a weak exothermic peak except complexes 3 and $\mathbf{4}$ which exhibited an endothermic peak. 


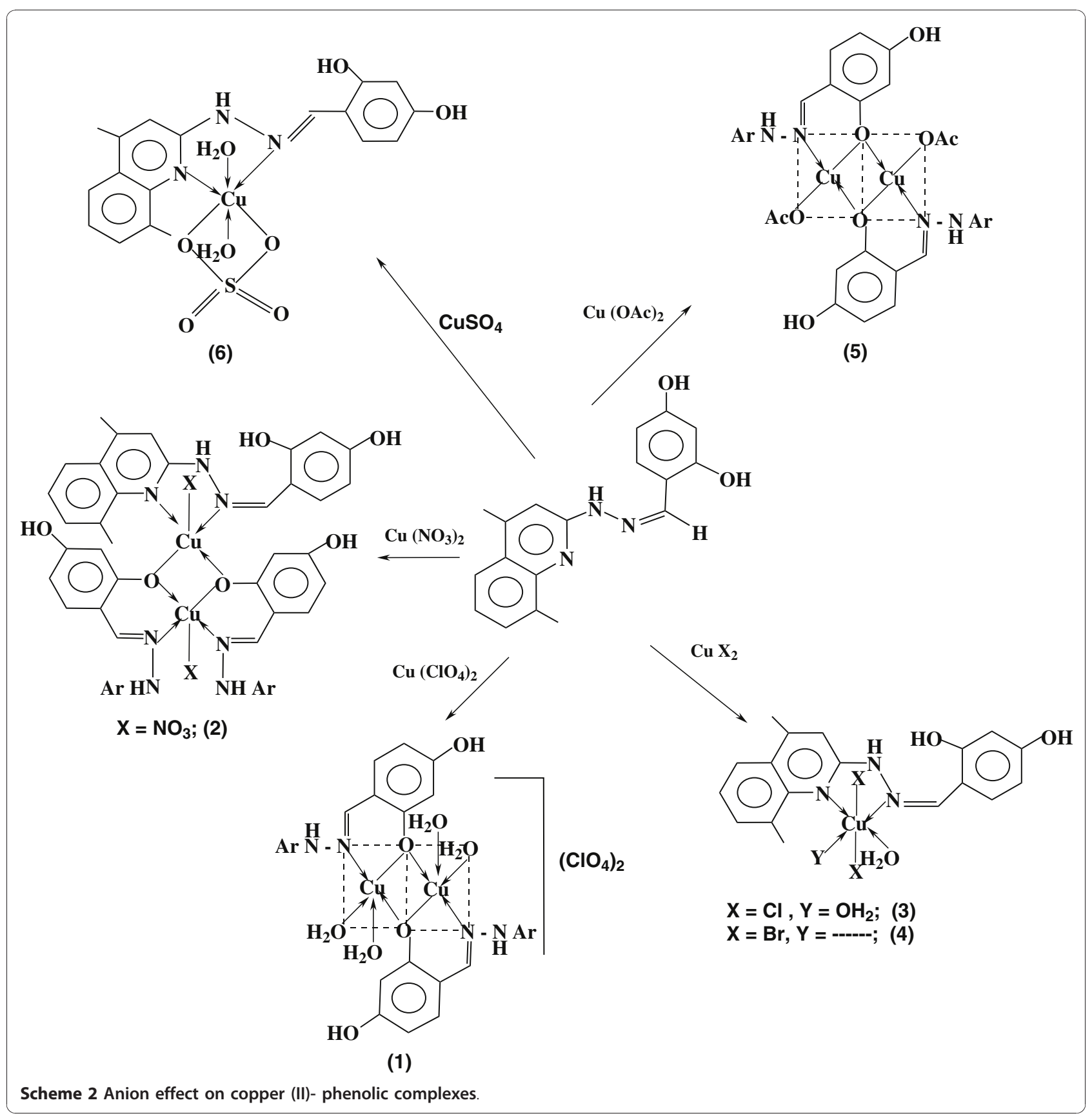

(ii) Elimination of the coordinated water molecules for some complexes is accompanied by loss of $\mathrm{HNO}_{3}$, $\mathrm{H}_{2} \mathrm{SO}_{4}, \mathrm{HBr}$ or AcOH acids via an exothermic or endothermic process depending on the nature of the complex and the removed acid. (iii) The TG-DSC thermogram of the perchlorato- complex (1) showed a sharp sudden inflection at $218^{\circ} \mathrm{C}$ with a mass loss; $94.13 \%$ via a very strong endothermic process $(\Delta \mathrm{H}=$ $830.2 \mathrm{~J} / \mathrm{g}$ ); a phenomenon related to $\mathrm{ClO}_{4}{ }^{-}$complexes [16] (Table 3). Metallic copper was obtained as the end product via further decomposition of $\mathrm{Cu}_{2} \mathrm{O}$ into $\mathrm{Cu}$.
Kinetic and thermodynamic parameters

The activation energy $\left(\mathrm{E}^{*}\right)$ of decomposition of the complexes as well as the collision factor (A) were evaluated graphically using the Coats- Redfern equation;

$$
\ln \left[\frac{-\ln (1-\alpha)}{T^{2}}\right]=\frac{-E^{*}}{R T}+\ln \left[\frac{A R}{\varphi E^{*}}\right]
$$

where $\alpha$ is the fraction of sample decomposed at temperature $T, \phi$ is the heating rate and $R$ is the gas constant. A plot of $\ln \left[-\ln (1-\alpha) / T^{2}\right.$ against $1 / \mathrm{T}$ gives a 
Table 2 Magnetic, conductivity, electronic and IR spectral data for the copper(II)- phenolic complexes

\begin{tabular}{|c|c|c|c|c|c|c|}
\hline \multirow[t]{2}{*}{ Complex } & \multirow[t]{2}{*}{$\lambda(\mathrm{nm})$} & \multirow{2}{*}{$\begin{array}{l}\mu_{\text {eff }} \\
\text { B.M. }\end{array}$} & \multirow{2}{*}{$\begin{array}{l}\text { Conductance } \\
\Omega^{-1} \mathrm{~cm}^{2} \mathrm{~mol}^{-1}\end{array}$} & \multicolumn{3}{|c|}{ IR spectral bands; $\mathrm{cm}^{-1}$} \\
\hline & & & & $v(\mathrm{OH})$ & $v(C=N)$ & Others \\
\hline $\mathrm{H}_{2} \mathrm{~L}$ & $266,320,371$ & -—— & -—— & 3426 & 1603 & -——- \\
\hline 1 & $285,348,461$ & 1.47 & 175.0 & 3422 & 1623 & $v(\mathrm{ClO}) ; 1094$ \\
\hline 2 & $276,346,435,460,485$ & 1.40 & 27.0 & 3423 & 1641 & $v(\mathrm{NO}) ; 1394$ \\
\hline 3 & $279,348,375,438$ & 1.95 & 40 & 3396 & 1613 & -——- \\
\hline 4 & $279,352,381,488$ & 1.77 & 32.0 & 3396 & 1622 & -——- \\
\hline 5 & $269,346,429,458$ & 1.33 & 9.2 & 3385 & 1612 & $v(C=0) ; 1635$ \\
\hline 6 & $268,287,371,436,460,485$ & 2.01 & 16.3 & 3385 & 1620 & $v_{3}(\mathrm{SO}) ; 1109$ \\
\hline
\end{tabular}

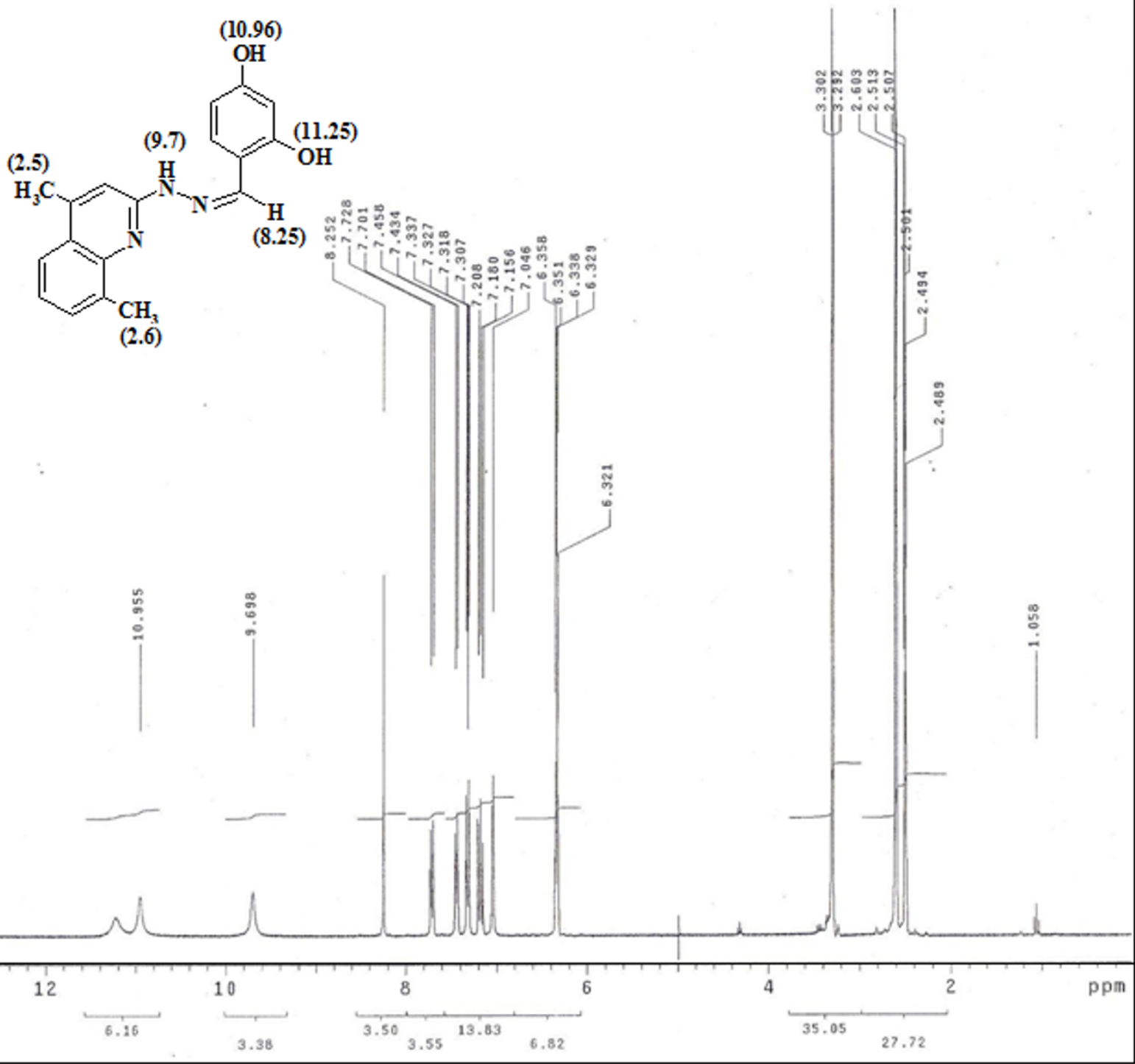

Figure $1{ }^{1}$ HNMR spectrum of the phenolic hydrazone; $\delta=7.05-7.73$ for aromatic protons $(7 \mathrm{H})$ 


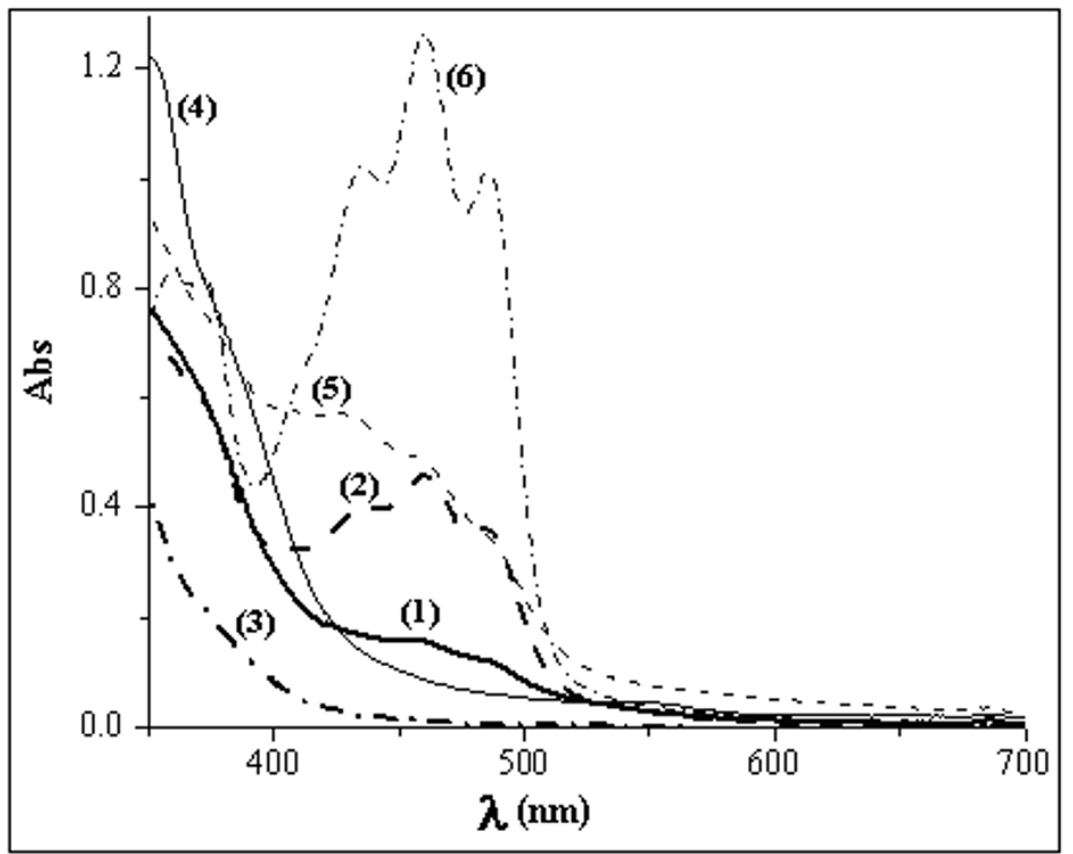

Figure 2 Overlay of the electronic spectra of copper (II) - phenolic complexes.

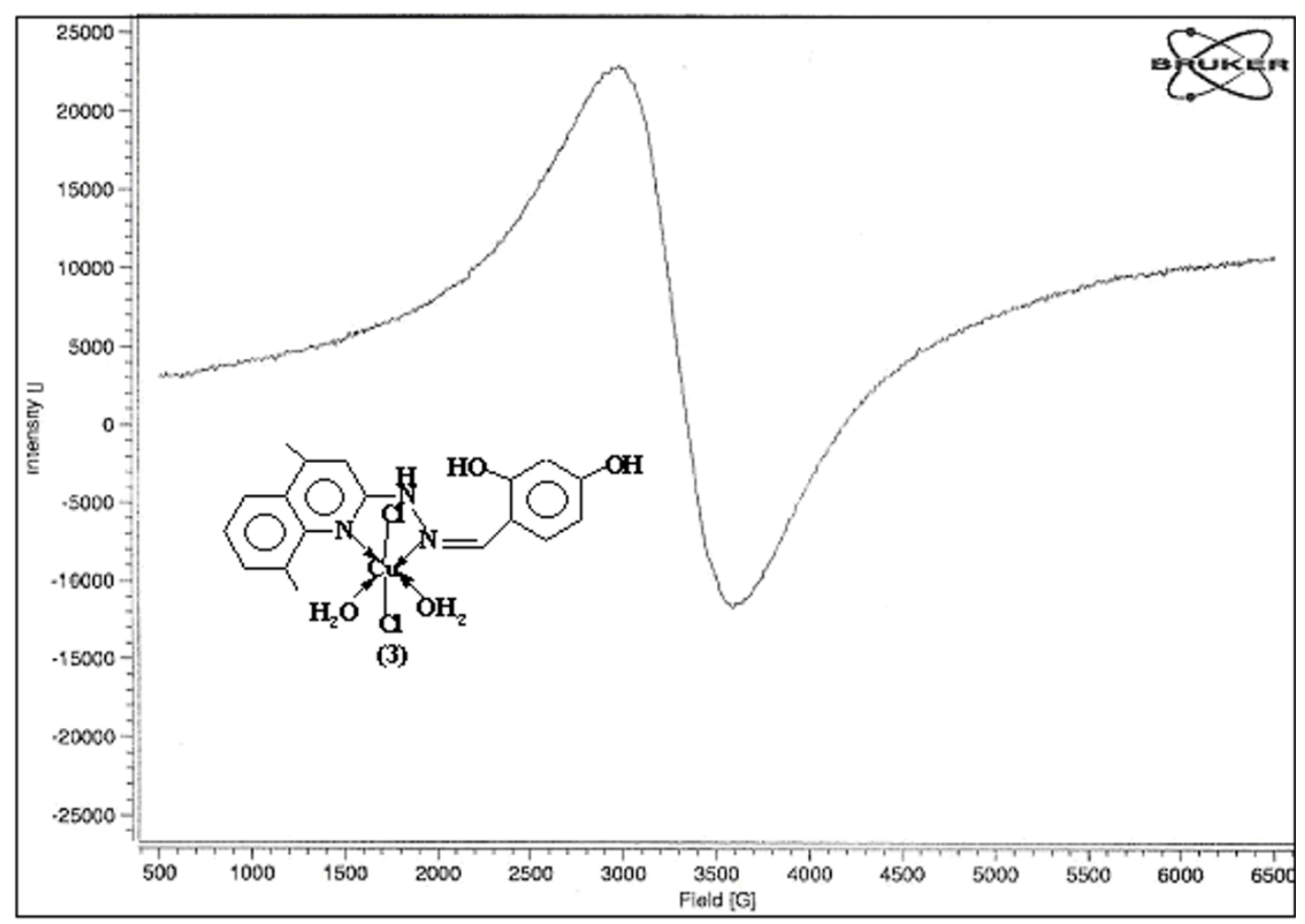

Figure 3 The X-band ESR spectrum of complex $3\left(O_{h}\right)$. 
Table 3 Thermal behavior of the copper(II)- phenolic complexes

\begin{tabular}{|c|c|c|c|c|c|}
\hline No. & Complex (F.W.) & $\begin{array}{l}\text { Temperature } \\
\text { range }\left({ }^{\circ} \mathrm{C}\right)\end{array}$ & $\begin{array}{l}\% \text { Wt. loss } \\
\text { Found/(Calcd.) }\end{array}$ & $\begin{array}{l}\text { Lost molecules; } \\
\text { Assignment }\end{array}$ & $\begin{array}{l}\text { Probable residue } \\
\text { Found/(Calcd.) }\end{array}$ \\
\hline 1 & $\begin{array}{c}{\left[\mathrm{Cu}(\mathrm{HL})\left(\mathrm{H}_{2} \mathrm{O}\right)_{2}\right]_{2}\left(\mathrm{ClO}_{4}\right)_{2} \cdot 1 / 2 \mathrm{H}_{2} \mathrm{O} .1 / 4 \mathrm{MeOH}} \\
(1027.76)\end{array}$ & $43-241$ & 94.13 & $\begin{array}{c}\text { * Decomp. in one step; } \\
\Delta \mathrm{H}=830.21 \mathrm{~J} / \mathrm{g}\end{array}$ & $\begin{array}{l}\text { Metallic Cu; } \\
5.87(6.17)\end{array}$ \\
\hline \multirow[t]{5}{*}{2} & $\begin{array}{c}{\left[\mathrm{Cu}_{2}(\mathrm{HL})_{2}\left(\mathrm{H}_{2} \mathrm{~L}\right)\left(\mathrm{NO}_{3}\right)_{2}\right] .11 / 4 \mathrm{H}_{2} \mathrm{O} \cdot 2^{3} / 4 \mathrm{MeOH}} \\
(1281.78)\end{array}$ & $46-105$ & $2.23(2.22)$ & $* 3 / 4 \mathrm{MeOH}+1 / 4 \mathrm{H}_{2} \mathrm{O}$ & \\
\hline & & $106-272$ & $17.07(16.23)$ & * $2 \mathrm{MeOH}+\mathrm{H}_{2} \mathrm{O}+2 \mathrm{HNO}_{3}$ & $\begin{array}{c}(\mathrm{CuO})_{2 i} \\
13.27(12.41)\end{array}$ \\
\hline & & $272-430$ & 51.68 & * Decomp. & \\
\hline & & $430-587$ & 15.75 & & \\
\hline & & $32-292$ & $9.54(11.3)$ & * $3 \otimes \mathrm{H}_{2} \mathrm{O}$ with decomp. & \\
\hline \multirow[t]{2}{*}{3} & 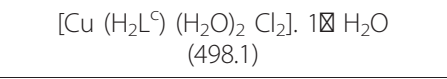 & 293-797 & 42.06 & & $\begin{array}{l}\left(\mathrm{Cu}_{2} \mathrm{O}+\mathrm{CuO}\right) \\
\quad 48.4(44.7)\end{array}$ \\
\hline & & $44-254$ & 12.6931 .00 & * Two overlapped steps; & \\
\hline \multirow[t]{3}{*}{4} & $\begin{array}{c}{\left[\mathrm{Cu}\left(\mathrm{H}_{2} \mathrm{~L}\right)\left(\mathrm{H}_{2} \mathrm{O}\right) \mathrm{Br}_{2}\right] \cdot 1 / 2 \mathrm{H}_{2} \mathrm{O}} \\
(557.72)\end{array}$ & $254-434$ & $18.28(33.8)$ & $* 11 / 2 \mathrm{H}_{2} \mathrm{O}+2 \mathrm{HBr}$ & $\begin{array}{l}\left(\mathrm{Cu}_{2} \mathrm{O}+\mathrm{Cu}\right)_{i} \\
34.0(37.0)\end{array}$ \\
\hline & & $434-800$ & 35.00 & $\rightarrow$ Decomp. & \\
\hline & & $29-268$ & $13.16(13.48)$ & $* 2 \mathrm{AcOH}$ & \\
\hline \multirow[t]{2}{*}{5} & $\begin{array}{c}{[\mathrm{Cu}(\mathrm{HL})(\mathrm{OAc})]_{2} \cdot \mathrm{MeOH}} \\
(889.91)\end{array}$ & $269-676$ & 66.94 & * MeOH with decomp. & $\begin{array}{l}\left(\mathrm{Cu}_{2} \mathrm{O}+\mathrm{Cu}\right)_{i} \\
19.9(23.2)\end{array}$ \\
\hline & & $28-145$ & $18.39(7.45)$ & * $2 \frac{1}{4} \mathrm{H}_{2} \mathrm{O}$ & \\
\hline \multirow[t]{2}{*}{6} & $\begin{array}{c}{\left[\mathrm{Cu}\left(\mathrm{H}_{2} \mathrm{~L}\right)\left(\mathrm{H}_{2} \mathrm{O}\right)_{2} \mathrm{SO}_{4}\right] \cdot 2^{1 / 1 / 4 \mathrm{H}_{2} \mathrm{O}}} \\
(543.52)\end{array}$ & $146-409$ & 19.01(18.03) & ${ }^{*} \mathrm{H}_{2} \mathrm{SO}_{4}$ & $\begin{array}{l}\left(\mathrm{Cu}_{2} \mathrm{O}+\mathrm{CuO}\right) \\
40.20(40.90)\end{array}$ \\
\hline & & 409-797 & 32.42 & * $2 \mathrm{H}_{2} \mathrm{O}$ with decomp. & \\
\hline
\end{tabular}

straight line whose slope $=-E^{*} / \mathrm{R}$ and its intercept $=\ln$ $\left[\mathrm{AR} / \phi \mathrm{E}^{*}\right]$. The activation entropy, enthalpy and free energy changes of the decomposition were calculated by the following equations:

$\Delta \mathrm{S}^{*}=2.303 \mathrm{R} \log (\mathrm{Ah} / \mathrm{KT}), \quad \Delta \mathrm{H}^{*}=\mathrm{E}^{*} \quad \mathrm{RT}$ and $\Delta \mathrm{G}^{*}=\Delta \mathrm{H}^{*} \quad \mathrm{~T} \Delta \mathrm{S}^{*}$

where h, $\mathrm{K}$ and T are the Planck's constant, Boltzmann's constant and the mid temperature in the TG thermogram, respectively. The evaluated kinetic and thermodynamic parameters of some complexes (Table 4) reflect the non spontaneity and the endothermicity of the decomposition stages as well as the orderness of the activated species. As shown from Table $4, \Delta H^{*}$ has comparable positive values and ranges from $2.805-3.752 \mathrm{k} \mathrm{J} \mathrm{mol}^{-1}$ for the first stage.

Table 4 Thermodynamic and kinetic parameters ${ }^{a}$ of copper(II)- phenolic complexes

\begin{tabular}{|c|c|c|c|c|c|c|c|}
\hline Complex & Stage & $\begin{array}{c}\mathrm{T} \\
(\mathrm{K})\end{array}$ & $\mathrm{A} \times 10_{1}^{-9} \mathrm{sec}^{-}$ & $E^{*}$ & $\Delta \mathrm{H}^{*}$ & $\Delta \mathrm{G}^{*}$ & $-\Delta S^{*}$ \\
\hline 1 & $1_{-}^{\text {st }}$ & 501 & 2.449 & 6.964 & 2.805 & 37.564 & 69.378 \\
\hline \multirow[t]{3}{*}{2} & $1_{-}^{\text {st }}$ & 348 & 1.368 & 5.786 & 2.898 & 27.671 & 71.187 \\
\hline & $2^{\text {nd }}$ & 500 & 5.509 & 9.112 & 4.962 & 36.277 & 62.63 \\
\hline & $3_{-}^{\text {rd }}$ & 626 & 35.499 & 15.451 & 10.256 & 40.948 & 49.029 \\
\hline 5 & $1_{-}^{\text {st }}$ & 470 & 3.248 & 7.653 & 3.752 & 35.009 & 66.503 \\
\hline \multirow[t]{2}{*}{6} & $1_{-}^{\text {st }}$ & 342 & 1.482 & 5.92 & 3.081 & 27.151 & 70.38 \\
\hline & $2^{\text {nd }}$ & 624 & 8.766 & 10.57 & 5.391 & 43.214 & 60.614 \\
\hline
\end{tabular}

\footnotetext{
${ }^{a} \mathrm{E}^{*}, \Delta \mathrm{H}^{*}$ and $\Delta \mathrm{G}^{*}$ are in $\mathrm{kJ} \mathrm{mol}{ }^{-1}$ while $\Delta \mathrm{S}^{*}$ is in $\mathrm{J} \mathrm{mol}^{-1} \mathrm{~K}^{-1}$.
}

Also, the values of $A, E^{*}, \Delta H^{*}$ and $\Delta G^{*}$ increase for the subsequent degradation steps, revealing the high stability of the remaining part as well as the lower rate of the removal of the subsequent species than that of the precedent one [22].

\section{Experimental}

Physical measurements

Microanalyses were carried out on a Perkin- Elmer 2400 $\mathrm{CHN}$ elemental analyzer. Analyses of the metal ions followed decomposition of their complexes with concentrated nitric acid. The resultant solution was diluted with doubly distilled water and filtered. The solution was then neutralized with aqueous ammonia solution and the metal ions titrated with EDTA. Thermal analyses (TG-DSC) were carried out on a Shimadzu- 50 thermal analyzer in nitrogen atmosphere and a heating rate of $20^{\circ} \mathrm{C} / \mathrm{min}$ using the TA-50 WS1 program. Electronic spectra were recorded on a Jasco V- 550 UV/VIS spectrophotometer. IR spectra were recorded on a Bruker Vector 22 spectrometer using $\mathrm{KBr}$ pellets. ESR spectra were recorded on a Bruker Elexsys, E 500 operated at X-band frequency. Mass spectra were recorded either at $70 \mathrm{eV}$ on a gas chromatographic GCMSQP 1000- EX Shimadzu mass spectrometer. ${ }^{1} \mathrm{H}$ NMR spectra were recorded as DMSO- $\mathrm{d}_{6}$ solutions on a Varian Mercury VX- 300 NMR spectrometer using TMS as an internal standard. Molar conductivity was measured as DMF solutions on the Corning conductivity meter NY 14831 

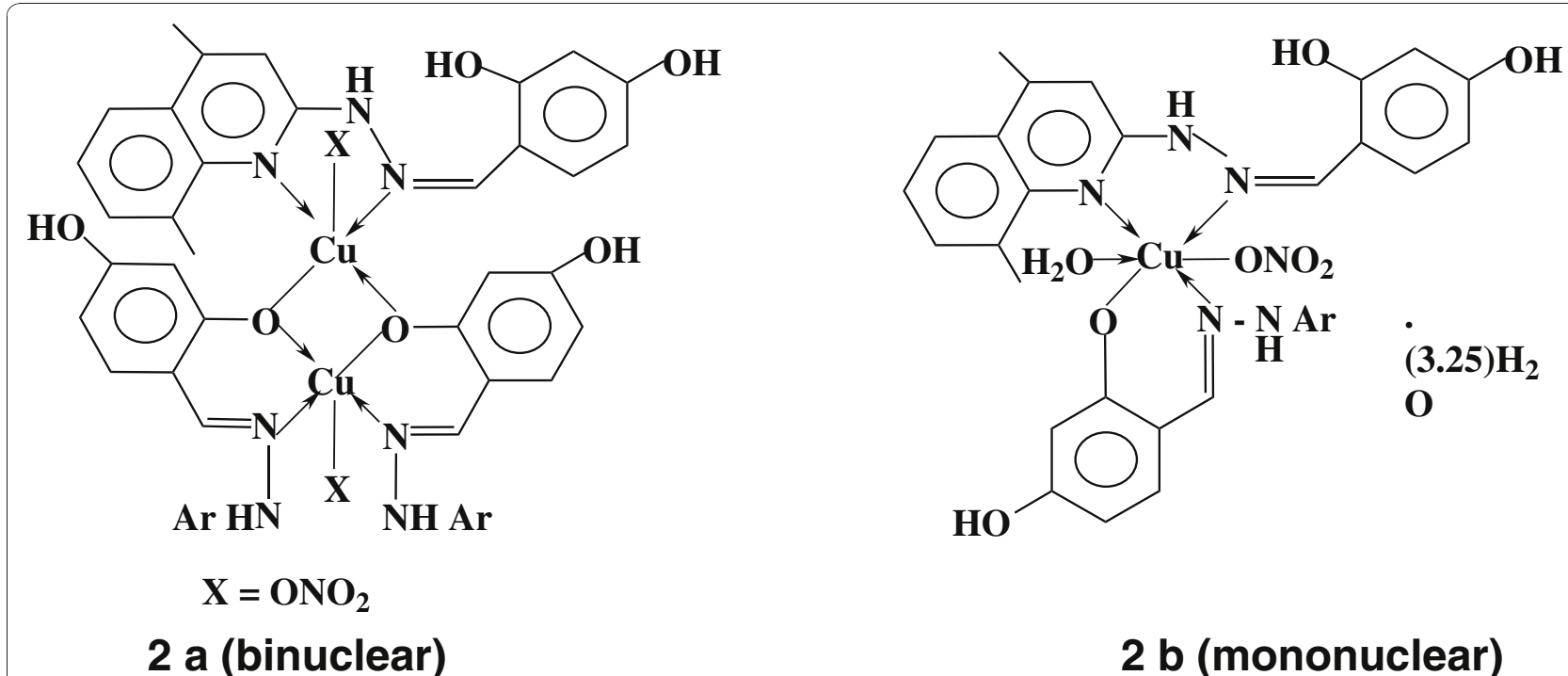

Scheme 3 Proposed structures of the nitrato complex (2).

model 441. Magnetic susceptibility of the complexes was measured at room temperature using a Johnson Matthey, MKI magnetic susceptibility balance. Melting points were determined using a Stuart melting point apparatus.

\section{Preparation of the phenolic hydrazone}

An ethanolic mixture of 2-hydrazinyl-4,8-dimethyl quinoline $(0.01 \mathrm{~mol})$ and 2,4-dihydroxybenzaldehyde $(0.012 \mathrm{~mol})$ was refluxed for $1 / 2 \mathrm{~h}$. The formed yellow compound was filtered off, washed with ethanol and crystallized from ethanol. The results of elemental analysis, \% yield and m.p ${ }^{\circ} \mathrm{C}$ are shown in Table 1.

\section{Synthesis of the complexes}

A general method has been used for the preparation of all complexes. A methanolic solution of the metal salt was added gradually to a methanolic solution of the phenolic hydrazone $\left(\mathrm{H}_{2} \mathrm{~L}\right)$ in the mole ratio $1: 1$; metal ion : ligand. Then, the reaction mixture was refluxed for 2-6 h where the solid complexes were precipitated, filtered off, washed with methanol and finally diethyl ether and then dried in vacuo. In general, the obtained complexes (Table 1) are colored and quite stable in atmospheric conditions. Also, most of the complexes have high melting points $(>300)$ indicating their strong bonds. The complexes are insoluble in water and most common solvents; but they are soluble in DMF and DMSO solvents.

\section{Conclusion and comments}

The ligational behavior of the phenolic hydrazone $\left(\mathrm{H}_{2} \mathrm{~L}\right)$ is highly affected by the type of the anion e.g. it behaves as a neutral NN bidentate donor in case of $\mathrm{Cl}^{-}, \mathrm{Br}^{-}$and $\mathrm{SO}_{4}{ }^{2-}$ anions (mononuclear complexes 3, 4 \& 6). Also, it acts as a mono basic $\mathrm{NO}$ donor with $\mathrm{O}$ - bridging in case of $\mathrm{ClO}_{4}{ }^{-}$and $\mathrm{AcO}^{-}$anions(dimeric complexes $\mathbf{1}$ $\& 5)$. The isolated complexes reflect the strong coordinating power of the $\mathrm{SO}_{4}{ }^{2-}, \mathrm{AcO}^{-}, \mathrm{Br}^{-}, \mathrm{Cl}^{-}$and $\mathrm{NO}_{3}{ }^{-}$ anions. Also, they reflect the structural diversity (octahedral, square pyramid and square planar) depending on the type of the counter anion (Scheme 2). In general, square planar, square pyramid and octahedral complexes rather than tetrahedral complexes usually arise from strong field ligands, the stronger the ligand, the more favored is the trans isomer. Also, the larger the size of the chelated ring (5- or 6- membered), the more favored is the trans arrangement (dimeric complexes 1 \&5). On the other hand, the binuclear complex 2 ( 2:3; M:L) has two proposed structures on basis of the results of elemental analysis $(\mathrm{CHN})$; Scheme 3 . However, the $\mu_{\text {eff }}$ value (Table 2) suggests two adjacent copper(II)- ions. Also, the \% metal ion content (Table 1) as well as the TG data (Table 3) are concordant with the binuclear structure (2a). From the interpretation of elemental and thermal analyses and spectral studies (infrared, electronic, mass and ESR) as well as magnetic susceptibility and molar conductivity measurements, it is possible to draw up the proposed structures of the copper(II)- complexes as shown in Scheme 2.

Authors' contributions

HSS conceived the study, participated in the sequence alignment and drafted the manuscript. GAE and BAE participated in the design of the study, analysis of the data and modification of the manuscript. HSS and MAM prepared and characterized the organic ligand and its complexes. All authors read and approved the final manuscript. 


\section{Competing interests}

The authors declare that they have no competing interests.

Received: 14 November 2010 Accepted: 11 January 2011

Published: 11 January 2011

\section{References}

1. Rollas S, Küçükgüzel Ș.G: Biological Activities of Hydrazone Derivatives. Molecules 2007, 12:1910-1939.

2. Vicini P, Incerti M, Doytchinova IA, La Colla P, Busonera B, Loddo R: Synthesis and antiproliferative activity of benzo[d]isothiazole hydrazones. Eur J Med Chem 2006, 41:624-632.

3. Tamasi G, Chiasserini L, Savini L, Sega A, Cini R: Structural study of ribonucleotide reductase inhibitor hydrazones. Synthesis and X-ray diffraction analysis of a copper(II)-benzoylpyridine-2-quinolinyl hydrazone complex. J Inorg Biochem 2005, 99:1347-1359.

4. El-Sherif AA: Synthesis, spectroscopic characterization and biological activity on newly synthesized copper(II) and nickel(II) complexes incorporating bidentate oxygen-nitrogen hydrazone ligands. Inorg Chim Acta 2009, 362:4991-5000.

5. Al-Hazmi GA, El-Asmy AA: Synthesis, spectroscopy and thermal analysis of copper(II) hydrazone complexes. J Coord Chem 2009, 62:337-345.

6. Sang YL, Lin X-S: Syntheses and crystal structures of two Schiff-base copper(II) complexes with antibacterial activities. J Coord Chem 2010, 63:315-322.

7. Ibrahim KM, Gabr IM, Zaky RR: Synthesis and magnetic, spectral and thermal eukaryotic DNA studies of some 2-acetylpyridine- [N-(3-hydroxy2-naphthoyl)] hydrazone complexes. J Coord Chem 2009, 62:1100-1111.

8. El-Behery M, El-Twigry H: Synthesis, magnetic, spectral, and antimicrobial studies of $\mathrm{Cu}(\mathrm{II}), \mathrm{Ni}(\mathrm{II}) \mathrm{Co}(\mathrm{II}), \mathrm{Fe}(\mathrm{III})$, and $\mathrm{UO}_{2}(\mathrm{II})$ complexes of a new Schiff base hydrazone derived from 7-chloro-4-hydrazinoquinoline. Spectrochimica Acta (A) 2007, 66:28-36.

9. Pouralimardan O, Chamayou A, Janiak C, Monfared H: Hydrazone Schiff base-manganese(II) complexes: Synthesis, crystal structure and catalytic reactivity. Inorg Chim Acta 2007, 360:1599-1608.

10. Basu C, Chowdhury S, Banerjee R, Evans HS, Mukherjee S: A novel blue luminescent high-spin iron(III) complex with interlayer $\mathrm{O}-\mathrm{H}$...Cl bridging: Synthesis, structure and spectroscopic studies. Polyhedron 2007, 26:3617-3624.

11. Bakir M, Green O, Mulder WH: Synthesis, characterization and molecular sensing behavior of $\left[\mathrm{ZnCl}_{2}\left(\mathrm{\eta}^{3}-\mathrm{N}, \mathrm{N}, \mathrm{O}-\mathrm{dpkbh}\right)\right]$ (dpkbh $=$ di-2-pyridyl ketone benzoyl hydrazone). J Mol Struct 2008, 873:17-28.

12. Seleem HS, El-Inany GA, Eid MF, Mousa M, Hanafy FI: Complexation of some Hydrazones Bearing the Quinoline Ring. Potentiometric Studies. J Barz Chem Soc 2006, 17:723-729.

13. Seleem HS, El-Inany GA, Mousa M, Hanafy Fl: Spectroscopic studies on 2[2-(4- methylquinolin-2-yl)hydrazono]-1,2-diphenylethanone molecule and its metal complexes. Spectrochim Acta (A) 2009, 74:869-874.

14. Seleem HS, El-Inany GA, Mousa M, Hanafy FI: Spectroscopic and pH-metric studies of the complexation of 3-[2-(4-methylquinolin-2-yl)hydrazono] butan-2-one oxime compound. Spectrochim Acta (A) 2010, 75:1446-1451.

15. Shebl M, Khalil SME, Al-Gohani F: Preparation, spectral characterization and antimicrobial activity of binary and ternary $\mathrm{Fe}(\mathrm{III}), \mathrm{Co}(\mathrm{II}), \mathrm{Ni}(\mathrm{II}), \mathrm{Cu}(\mathrm{II})$, $\mathrm{Zn}(\mathrm{II}), \mathrm{Ce}(\mathrm{III})$ and $\mathrm{UO2}(\mathrm{VI})$ complexes of a thiocarbohydrazone ligand. J Mol Struct 2010, 980:78-87.

16. Seleem HS, El-Shetary BA, Khalil SME, Mostafa M, Shebl M: Structural diversity in copper(II) complexes of bis(thiosemicarbazone) and bis (semicarbazone) ligands. J Coord Chem 2005, 58:479-493.

17. Ghosh T, Bhattacharya S, Das A, Mukherjee G, Drew M: Synthesis, structure and solution chemistry of mixed-ligand oxovanadium(IV) and oxovanadium(V) complexes incorporating tridentate ONO donor hydrazone ligands. Inorg Chim Acta 2005, 358:989-996.

18. Nakamoto K: Infrared Spectra of Inorganic and Coordination Compounds. Willey, New York; 1970

19. Shebl M, Seleem HS, El-Shetary BA: Ligational behavior of thiosemicarbazone, semicarbazone and thiocarbohydrazone ligands towards VO(IV), $\mathrm{Ce}(\mathrm{IIII}), \mathrm{Th}(\mathrm{IV})$ and UO2(VI) ions: Synthesis, structural characterization and biological studies. Spectrochim Acta (A) 2010, 75:428-436.

20. Emara AAA: Structural, spectral and biological studies of binuclear tetradentate metal complexes of N3O Schiff base ligand synthesized from 4,6-diacetylresorcinol and diethylenetriamine. Spectrochimica Acta (A) 2010, 77:117-125.

21. Hassanien MM, Gabr IM, Abdel-Rhman MH, El-Asmy AA: Synthesis and structural investigation of mono- and polynuclear copper complexes of 4-ethyl-1-(pyridin-2-yl) thiosemicarbazide. Spectrochimica Acta (A) 2008, 71:73-79.

22. El-Asmy AA, Al-Gammal OA, Saad DA, Ghazy SE: Synthesis, characterization, molecular modeling and eukaryotic DNA degradation of 1-(3,4-dihydroxybenzylidene)thiosemicarbazide complexes. J Mol Struct 2009, 934:9-22.

doi:10.1186/1752-153X-5-2

Cite this article as: Seleem et al:: The ligational behavior of a phenolic quinolyl hydrazone towards copper(II)- ions. Chemistry Central Journal 2011 5:2.

\section{Publish with ChemistryCentral and every scientist can read your work free of charge \\ "Open access provides opportunities to our colleagues in other parts of the globe, by allowing anyone to view the content free of charge." W. Jeffery Hurst, The Hershey Company. \\ - available free of charge to the entire scientific community \\ - peer reviewed and published immediately upon acceptance \\ - cited in PubMed and archived on PubMed Central \\ - yours - you keep the copyright \\ Submit your manuscript here: \\ http://www.chemistrycentral.com/manuscript/<smiles>c1ccccc1</smiles> \\ ChemistryCentral}

